\title{
GROWTH PERFORMANCE AND IMMUNITY RESPONSE OF SUCKLING FRIESIAN CALVES FED ON RATION SUPPLEMENTED WITH ORGANIC OR NANO SELENIUM PRODUCED BY LACTIC ACID BACTERIA
}

\author{
A.Sh. Shams ${ }^{1}$, M.A. Zommara ${ }^{2}$, M.E. Sayed-Ahmed ${ }^{1}$ and M.M. El-Nahrawy $^{1}$ \\ ${ }^{1}$ Animal Production Research Institute, Agricultural Research Center, Dokki, Giza, Egypt. \\ ${ }^{2}$ Department of Dairy Science, Fac. of Agric., Kafrelsheikh Univ., Kafr El-Sheikh, 33516, Egypt.
}

(Received 2/1/2020, accepted 9/2/2020)

SUMMARY

$\mathrm{E}$

ighteen suckling Friesian calves with average live body weight of $32.70 \pm 0.79 \mathrm{~kg}$ were divided into three comparable groups based on sex and birth weight. All calves were fed on a whole milk, starter and berseem hay without supplement in the control group or supplemented with $0.3 \mathrm{mg} \mathrm{Se} / \mathrm{kg} \mathrm{DM}$ intake as organic selenium (OSe) or nano selenium (NSe) for $2^{\text {nd }}$ and $3^{\text {rd }}$ groups. The results showed that organic-and nano selenium groups recorded significantly $(\mathrm{P}<0.05)$ higher digestibility of DM, OM, CP, CF, EE and NFE as well as TDN, DE and DCP compared to the control group, Plasma total protein concentration was not significantly $(\mathrm{P}>0.05)$ affected by selenium additives. While, albumin concentration and albumin to globulin ratio were significantly $(\mathrm{P}<0.05)$ decreased, however, globulin concentration in plasma of calves supplemented with OSe and NSe was significantly $(\mathrm{P}<0.05)$ higher than that of control group, Organic and nano selenium supplementation significantly decreased $(\mathrm{P}<0.05)$ the activity of AST and ALT enzymes and creatinine concentration in plasma compared to that of the control group. The concentrations of IgA and IgG in plasma were increased significantly $(\mathrm{P}<0.05)$ with OSe and NSe supplementation compared to the control group, The IgM concentration was comparable among all groups. The percentages of various disease incidence decreased significantly $(\mathrm{P}<0.05)$ in OSe and NSe supplemented groups than those of the control group, Morality rate was higher in the control group than that of OSe group, however no mortality was observed in calves of NSe group. Dry matter intake values were the same for different groups, whereas, values of TDN and DCP intake tended to increase with OSe and NSe supplemented diet than those of the control group. Birth weight was comparable among all groups. While, weaning weight, total weight gain and average daily weight gain were significantly $(\mathrm{P}<0.05)$ higher for OSe and NSe groups than to the control. Supplementation with OSe and NSe improved feed conversion ratio, which significant decreased $(\mathrm{P}<0.05)$, where the amounts of DM, TDN and DCP per one $\mathrm{kg}$ weigh gain were less than those of control group. Daily feed cost was comparable among all groups, where feed cost per kg gain was significantly $(\mathrm{P}<0.05)$ lower for OSe and NSe groups than control group. The cost price of daily weight gain and net revenue as well as economic efficiency were significantly $(\mathrm{P}<0.05)$ higher for OSe and NSe groups compared to those of control group.

Keywords: Nano selenium, Organic selenium, suckling calves, digestibility, blood biochemical, immunity response, mortality rate, weight gain, feed conversion and economic efficiency.

\section{INTRODUCTION}

Selenium (Se) is a trace mineral found in the soil. It appears naturally in water and some feeds. Although people need a very small amount of selenium, it plays one of a key role in the metabolism, It plays on important role in reproduction, thyroid hormone metabolism, synthesis of DNA, and protection from infectious diseases and oxidative damage (Sunde, 2012, Terry and Diamond, 2012). The recommended daily allowance of Se for adult male and female is about $55 \mu \mathrm{g}$ (FNB, 2000). Selenium exists in two forms, inorganic and organic (selenomethionine and selenocysteine) (Sunde, 2012). Both of two forms are good dietary sources of selenium (Terry and Diamond, 2012). Soils contain inorganic selenites and selenates that plants accumulate and converted to organic forms, mostly selenocysteine and selenomethionine and their methylated derivatives (Ježek, et al., 2012). 


\section{Shams et al.}

Nano-Se (nano-elemental Se) is another form of inorganic Se. It is bright red, highly stable, and of nanosize in the redox state of zero $\left(\mathrm{Se}^{0}\right)$. There are several methods to obtain selenium nanoparticles (SeNPs). It can be chemically synthesized (Zhang et al., 2004) or through physical procedures (Quintana et al., 2002) or by biological way, this so-called green synthesis, using microorganisms or plant extracts, (Prokisch and Zommara, 2011, Ramamurthy et al., 2013, Shoeibi and Mashreghi, 2017). The green synthesis of SeNPs using microorganisms takes more attention for its simplicity, high purity, producing of a uniform and stable SeNPs.

Adding $0.8 \mathrm{mg}$ of organic Se to suckling calves increased the serum levels of this trace mineral in the animals and enhances their immune systems at 30 days of age. A superior immune parameter response was observed in calves supplemented with Se to the abomasum. In addition, Se supplementation maintained the performance of animals that had a diagnosis of diarrhea. Selenium supplementation did not act as a growth promoter but improved immune system function during this phase of compromised health (Salles et al., 2013).

Supplementation of selenium nanoparticles gave the best performance in terms of increasing serum globulin level, reducing A:G ratio, and improving humoral immune status in male Wistar rats at the level of $150 \mathrm{ppb}$ (Bunglavan et al., 2014).

Selenium has attracted much attention recently in human and animal food. Even though selenium in high level is toxic, in trace amounts it exerts various beneficial effects in vivo. Selenium supplementation was found to enhance muscle development and the growth rate. Selenium influences the immune response by the activation of phagocytosis, increasing antibody production and enhancing lymphocyte proliferation. Supplementation of selenium on buffalo calves diet at 8 to 9 months of ages had increased the blood globulin which led to improved immunity status (Mudgal et al., 2008).

Guyot et al. (2007) found that calves fed diets with yeast rich organic selenium (Y-Se) located higher growth rate when given at the rate of $0.5 \mathrm{ppm}$ compared with calves fed diets containing inorganic selenium as sodium selenite. Lambs fed diet with $0.15 \mathrm{ppm}$ selenium as organic selenium (Jevsel-101) or sodium selenite recorded humoral immune response, antioxidant and improved growth rate, compared with control group without supplementation (Kumar et al., 2009) while, the effect was higher for organic selenium group than those fed inorganic selenium supplemented diet.

Vinu et al. (2012) indicated that added selenium yeast at the rate of $0.3 \mathrm{ppm}$ to diets of cross bred calves improved their disease resistance. Selenium was first given importance attention because of its toxicity, later selenium known as an important element for animals for developing proper immune mechanism against the invaders and for various life activities. There is only a narrow gap between dietary essential dose and toxic dose. Exceed of selenium are toxicity and leads to alkali disease while, deficiency of selenium leads to white muscle disease in calves. So, FDA (Food and Drug Administration) recommended (0.3 ppm) supplementation of selenium in the diet. Recent research indicated that organic form of selenium is more efficiency than inorganic Selenium. (Nampoothiri and Gangadevi, 2017) found that support animals with right amount of Selenium keep the animal in a good health condition and right growth performance.

The objective of the current work was to investigate the effect of nano and organic selenium supplementation on nutrient digestibilities, some blood biochemical changes, immunity response, health status, mortality rate, growth performance, feed conversion and economic efficiency of suckling Friesian calves fed on ration supplemented with organic or nano selenium produced by lactic acid bacteria.

\section{MATERIALS AND METHODS}

The current work was carried out at El-Karda Animal Production Research Station, Animal Production Research Institute, Agricultural Research Center, Ministry of Agriculture, during year 2017/2018.

\section{Production of organic nano-selenium (NSe):}

Organic selenium (OSe) was produced by lactic acid bacteria as described by Zommara and Prokisch (2015). The ability of yoghurt culture to completely uptake and bio-convert $1 \mathrm{ppm}$ of the inorganic selenium to organic form in the cultured media, suggested applied, as indicative of a real opportunity to produce fortified yoghurt with organic selenium. 
Also, nano selenium spheres (NSe) were produced by lactic acid bacteria as described by Prokisch et al. (2008). Pure yoghurt culture was obtained from Microbiological Resource Centre, Ain Shams University (MIRCEN), Cairo. Yoghurt culture (Lactobacillus delbrueckii subsp. bulgaricus and Streptococcus thermophilu $)$ were mixed $(1: 1, \mathrm{w} / \mathrm{w})$ and cultivated in whey yeast extract media as described by Kar and Misra (1999) fortified with $1 \%$ yeast extract and 0.1\% skim milk powder (Parente and Zottola, 1991). The media were amended with $100 \mathrm{ppm}$ of filter sterilized (Sartorius AG, Germany) selenium Se (IV) (sodium selenite, $\mathrm{Na}_{2} \mathrm{SeO}_{3} .5 \mathrm{H}_{2} \mathrm{O}$, Sigma-Aldrich, Switzerland) and incubated at $40^{\circ} \mathrm{C}$ up to $24 \mathrm{~h}$. According to the electronmicroscopy pictures, the size of spheres was in the range of $50-100 \mathrm{~nm}$

\section{Animals and diets:}

Eighteen suckling Friesian calves with average live body weight of $32.70 \pm 0.79 \mathrm{~kg}$ were divided into three comparable groups based on sex and birth weight. All calves were fed on a whole milk, starter and berseem hay without supplement in first group (Control) or supplemented with $0.3 \mathrm{mg} \mathrm{Se} / \mathrm{kg}$ DM intake as organic selenium (OSe) in the second group or $0.3 \mathrm{mg} \mathrm{Se} / \mathrm{kg}$ DM intake as NSe in the third group Water and diets were provided ad libitum. Calves were removed from their dams after having their colostrums for 3 days and artificially fed whole milk in plastic bucket twice daily at 7 a.m. and 6 p.m. From the beginning of the third week, calves were given the starter feed once daily at 9 a.m. and berseem hay once time at 11 a.m. Selenium additives was supplemented in the whole milk during the morning suckling and water was freely provided during the experimental period, (105 days)

Calves were fed according to the recommended requirements of Animal Production Research Institute (1997) as shown in Table (1). Chemical composition of tested feedstuffs is presented in Table (2).

Table (1): Average daily feedstuffs intake $(\mathrm{kg} / \mathrm{head} / \mathrm{day})$ during suckling period.

\begin{tabular}{lcccccccc}
\hline \multirow{2}{*}{ Feedstuff* } & \multicolumn{7}{c}{ Age (week) } \\
\cline { 2 - 9 } & $1-2$ & $3-4$ & $5-6$ & $7-8$ & $9-10$ & $11-12$ & $13-14$ & 15 \\
\hline Whole milk & $3.5-4.0$ & $4.5-5.0$ & $5.0-4.5$ & $4.0-3.5$ & $3.0-2.5$ & $2.0-1.75$ & $1.5-1.25$ & 1 \\
Calf starter & - & 0.25 & 0.50 & 0.75 & 1.00 & 1.25 & 1.50 & 1.75 \\
Berseem hay & - & 0.1 & 0.2 & 0.3 & 0.4 & 0.5 & 0.6 & 0.7 \\
\hline
\end{tabular}

*As fed.

Table (2): Feedstuffs composition during suckling period.

\begin{tabular}{lccccccc}
\hline \multirow{2}{*}{ Item } & \multirow{2}{*}{ DM \% } & \multicolumn{7}{c}{ Composition of DM \% } \\
\cline { 3 - 8 } & & OM & CP & CF & EE & NFE & Ash \\
\hline Whole milk & 11.80 & 93.80 & 23.95 & 00.00 & 29.30 & 40.55 & 6.20 \\
Calf starter* & 91.45 & 91.75 & 17.90 & 5.95 & 3.35 & 64.55 & 8.55 \\
Berseem hay & 88.65 & 90.75 & 12.50 & 27.35 & 2.40 & 48.50 & 11.35 \\
\hline
\end{tabular}

* Starter consisted of $15 \%$ soybean meal, $10 \%$ linseed cake, $34 \%$ ground yellow corn grain, $20 \%$ wheat bran, $15 \%$ rice bran, $3 \%$ molasses, $2 \%$ limestone and $1 \%$ common salt.

\section{Nutrients Digestibility:}

Digestibility trial was conducted in the last week of the experiment using all animals to determine nutrients digestibility coefficients and nutritive values using acid insoluble ash as a natural marker (Van Keulen and Young, 1977). Feces samples were taken from the rectum of each calf twice daily with 12 hours interval for seven days collection period. Samples of whole milk, starter and berseem hay were taken at the beginning, middle and end of the collection period. The samples of starter, berseem hay and feces were composted and representative samples were dried in a forced air oven at $65{ }^{\circ} \mathrm{C}$ for 48 hours, ground and analyzed DM, CP, EE, CF, NFE, according to AOAC (1990). Whole milk samples were analyzed using Milko-Scan (133 B Foss Electric).

DM digestibility $\%=100-[100 \times($ AIA $\%$ in feed $/$ AIA $\%$ in feces $)]$

Nutrient digestibility $\%=$

$100-[100 \times($ AIA $\%$ in feed $/ \%$ feces $) \times($ nutrient $\%$ in feces $/$ nutrient $\%$ in feed $)]$ 


\section{Shams et al.}

\section{Animal growth parameters:}

Calves were weighed weekly in the morning before drinking and feeding to the nearest $0.1 \mathrm{~kg}$ for each animal during the suckling period and average daily body weight gain was calculated. Feed efficiency was calculated as the amounts of DM, TDN and DCP per kg body weight gain. The occurrence of diarrhea, respiratory, septicemia, navel and general weakness diseases as well as the mortality was observed and recorded daily for calves in each group.

\section{Blood analysis:}

At end of the feeding period blood samples were taken from the jugular vein of each calves by clean sterile needle in clean dry glass tubs using heparin as an anticoagulant and centrifuged for 15 minutes at 4000 rotations per minute to obtain plasma. Plasma samples were kept in deep freezer at $-20{ }^{\circ} \mathrm{C}$ till chemical analysis was carried out. Total protein and albumin concentrations were determined using commercial kits supplied by Randox (Randox Laboratories Ltd, Crumlin, Co, Antrim, UK) according to Henry et al. (1974). Globulin concentration was estimated by subtracting the values of albumin from the corresponding values of total protein per sample. Activities were detrmined plasma aspartate amino transferase (AST) and alanine amino transaminase (ALT) according to Hafkenscheid and Dijt (1979) and creatinine concentration according to Chasson et al. (1961) using commercial kits (Bio-Merieux Laboratory Reagents and Products France) according to the manufacturer procedure. The concentrations of immunoglobulins $\operatorname{IgG}, \operatorname{IgM}$ and $\operatorname{Ig} \mathrm{A}$ concentrations in blood plasma were measured using the quantitative ELISA Bovine (IgG, IgM and IgA), ELISA Quantitation Kit, Bethyl laboratories, UK.

\section{Economic efficiency:}

Economic efficiency was calculated as the ratio between the income of the average daily body weight gain and the cost of average daily feed cost as follows:

Economic efficiency $=$ output of daily weight gain/ cost of daily feed consumed

Where, the price of $1 \mathrm{~kg}$ was 4.50 LE for the whole milk, 5.45 LE for the starter, 3.00 LE for berseem hay and 85 LE for body weight gain throughout year 2018.

\section{Statistical analysis:}

The data were analyzed using the general linear model procedure adapted by IBM SPSS Statistics (2014) for user's guide with one-way ANOVA. Significant differences in the mean values among dietary treatments were analyzed by Duncan's tests within SPSS program set at the level of significance $\mathrm{P}<0.05$.

\section{RESULTS AND DISCUSSION}

\section{Nutrients digestibility and nutritive values:}

Digestibility coefficients and nutritive values of the experimental rations by experimental suckling Friesian calves are presented in Table (3). Groups received OSe and NSe recorded significantly $(\mathrm{P}<0.05)$ the highest digestibility of DM, OM, CP, CF, EE and NFE as well as total digestible nutrients (TDN), digestible energy (DE) and digestible crude protein (DCP) compared to the control group. Selenium is an important dietary micronutrient required for metabolism of animals and the normal body functions, it plays a significant role in the catalytic processes within the enzyme system that consist of a variety of enzyme activities linked with the metabolic, endocrine, and immune systems (Keen et al., 2004). Serra et al. (1994) showed that addition of $4 \mathrm{~g} / \mathrm{kg}$ dietary dry matter, nano-selenium (NS) could significantly increase growth and activity of cellulolytic bacteria compared to selenium yeast (YS) and thus enhance fermentation in the rumen. This helped us to clarify the different metabolic ways that taken place for inorganic Se and organic Se in rumen. Xun et al. (2012) found that DM, organic matter (OM), crude protein (CP), ether extract (EE), $\mathrm{NDF}$, and ADF digestibility in the total tract of sheep were lower in in control non supplemented sheep than Se supplemented animals at level of $(\mathrm{P}<0.01)$, and also with significantly $(\mathrm{P}<0.01)$ higher values in NS group compared to SY group. Ibrahim (2017) stated that nutrient digestibility of DM, OM, EE and NFE increased $(\mathrm{P}<0.05)$ for lambs of supplemented with selenium and vit. E than untreated (control). Abd ElHafez et al. (2016) found that vitamin E plus Se supplement improved $(\mathrm{P}<0.01)$ digestibility coefficients of DM, OM, CP, EE, NFE and feeding values (TDN and DCP) in Sohagi lambs. These findings explained by 
the fact that vitamin $\mathrm{Se}$ and $\mathrm{E}$, as necessary elements of the antioxidant defense system, play a complementary role in metabolism through their participation in critical enzymes and enzyme reactions (Willshire and Payne, 2011).

Table (3): Digestion coefficients and nutritive values of the experimental rations by suckling Friesian calves.

\begin{tabular}{lcccc}
\hline \multirow{2}{*}{ Item } & \multicolumn{3}{c}{ Treatment } & \multirow{2}{*}{ SEM } \\
\cline { 2 - 4 } & Control & OSe & NSe & \\
Digestibility coefficients \% & & & & \\
DM & $69.60^{\mathrm{b}}$ & $74.16^{\mathrm{a}}$ & $72.85^{\mathrm{a}}$ & 0.79 \\
OM & $71.30^{\mathrm{b}}$ & $75.43^{\mathrm{a}}$ & $74.27^{\mathrm{a}}$ & 0.81 \\
CP & $68.35^{\mathrm{b}}$ & $73.49^{\mathrm{a}}$ & $71.59^{\mathrm{a}}$ & 0.86 \\
CF & $55.25^{\mathrm{a}}$ & $58.29^{\mathrm{a}}$ & $57.87^{\mathrm{a}}$ & 0.58 \\
EE & $77.90^{\mathrm{b}}$ & $80.91^{\mathrm{a}}$ & $79.20^{\mathrm{a}}$ & 0.63 \\
NFE & $75.60^{\mathrm{b}}$ & $78.98^{\mathrm{a}}$ & $77.47^{\mathrm{a}}$ & 0.66 \\
Nutritive values & & & & \\
TDN \% & $76.21^{\mathrm{b}}$ & $79.34^{\mathrm{a}}$ & $78.35^{\mathrm{a}}$ & 0.70 \\
DE (Mcal/kg DM) & $3.36^{\mathrm{b}}$ & $3.52^{\mathrm{a}}$ & $3.45^{\mathrm{a}}$ & 0.03 \\
DCP \% & $12.51^{\mathrm{b}}$ & $13.46^{\mathrm{a}}$ & $13.11^{\mathrm{a}}$ & 0.16 \\
\hline
\end{tabular}

$a, b$ : Means in the same row with unlike superscripts are significantly different $(P<0.05)$.

\section{Blood plasma biochemical Changes:}

Values of blood plasma biochemical of suckling Friesian calves as affected by selenium supplementation are presented in Table (4). Total protein concentration of plasma was not shown different affect at the level of $(\mathrm{P}>0.05)$ when added selenium. While, albumin concentration and albumin to globulin (A:G) ratio in blood plasma of control group were significantly $(\mathrm{P}<0.05)$ higher compared to OSe and NSe groups. However, globulin concentration in plasma of calves supplemented with OSe and NSe was significantly $(\mathrm{P}<0.05)$ higher than that of control group. Moreover, OSe and NSe supplementation improved liver and kidney functions, where the activity of AST and ALT enzymes and creatinine concentration of calves in control group were significantly $(\mathrm{P}<0.05)$ higher than those of OSe and NSe groups. These results agreed with those obtained by Bunglavan et al. (2014) who found that supplementation of Se nanoparticles reduced A:G ratio and improved the mean serum globulin level, but not affected total protein level in serum. Ibrahim (2017) reported that lambs fed on selenium had higher $(\mathrm{P}<0.05)$ concentrations of serum total protein and globulin vs. control or vit. E supplemented diet.

Table (4): Blood plasma biochemical and immunity response of suckling Friesian calves.

\begin{tabular}{lcccc}
\hline \multirow{2}{*}{ Item } & \multicolumn{3}{c}{ Treatment } & \multirow{2}{*}{ SEM } \\
\cline { 2 - 3 } & Control & OSe & NSe & \\
\hline Plasma biochemical & & & & \\
Total protein (g/dl) & 6.72 & 6.74 & 6.70 & 0.12 \\
Albumin (g/dl) & $3.47^{\mathrm{a}}$ & $2.99^{\mathrm{b}}$ & $2.97^{\mathrm{b}}$ & 0.11 \\
Globulin (g/dl) & $3.25^{\mathrm{b}}$ & $3.75^{\mathrm{a}}$ & $3.73^{\mathrm{a}}$ & 0.11 \\
Albumin: globulin ratio & $1.06^{\mathrm{a}}$ & $0.80^{\mathrm{b}}$ & $0.80^{\mathrm{b}}$ & 0.07 \\
AST (IU/l) & $31.83^{\mathrm{a}}$ & $24.50^{\mathrm{b}}$ & $25.67^{\mathrm{b}}$ & 1.97 \\
ALT (IU/l) & $20.50^{\mathrm{a}}$ & $9.00^{\mathrm{b}}$ & $11.67^{\mathrm{b}}$ & 1.59 \\
Creatinine (mg/dl) & $0.97^{\mathrm{a}}$ & $0.81^{\mathrm{b}}$ & $0.80^{\mathrm{b}}$ & 0.08 \\
Immunity response & & & & \\
IgA (mg/dl) & $27.00^{\mathrm{b}}$ & $33.35^{\mathrm{a}}$ & $31.67^{\mathrm{a}}$ & 1.04 \\
IgM (mg/dl) & 10.13 & 8.48 & 8.87 & 0.54 \\
IgG (mg/dl) & $137.05^{\mathrm{b}}$ & $161.00^{\mathrm{a}}$ & $157.75^{\mathrm{a}}$ & 2.79 \\
\hline
\end{tabular}

$a, b$ : Means in the same row with unlike superscripts letters are significantly different $(P<0.05)$. 


\section{Shams et al.}

\section{Immunity response:}

Results of immunity response in Table (4) revealed that the concentrations of IgA and IgG fractions increased significantly $(\mathrm{P}<0.05)$ with OSe and NSe supplementation compared to non-supplemented group (control). Whereas, IgM fraction was not significantly $(\mathrm{P}>0.05)$ affected by selenium supplementation and tended to increase in control group. Reffett et al. (1988) clarified that supplemented diet with selenium stimulated primary and secondary immune response in calves challenged with infectious bovine rhinotracheitis virus. They indicated that selenium supplemented group at $(0.2 \mathrm{mg} / \mathrm{kg}$ diet $)$ increase whole blood and plasma GSH-Px activity. Gill and Walker (2008) stated that elaborated spleen lymphocyte were proliferated indicating improved immune response of selenium fed rats fed selenium diet at $(121 \mu \mathrm{g} / 100 \mathrm{~g}$ feed) for forty nine days compared with control rats fed selenium at (18 $\mu \mathrm{g} / 100 \mathrm{~g}$ feed) Vinu et al. (2012) found that crossbred calves fed selenium yeast at the rate of $0.3 \mathrm{ppm}$ reduced the chance of getting sick. It was olsonoted that selenium is important for the regulation of immunity functions (Köhrle and Gärtner, 2009), plays an essential role in non-specific immune response (Dercksen et al., 2007) and its low level is related to weakened immune system (Effraimidis and Wiersinga, 2014).

\section{Health status and mortality rate:}

Data of health status of experimental suckling Friesian calves shown in Table (5) revealed that the percentages of various disease incidence decreased significantly $(\mathrm{P}<0.05)$ in OSe and NSe supplemented groups than those of control group. The percentage of total calves infection decreased significantly $(\mathrm{P}<0.05)$ from $70.50 \%$ in control group to $42.10 \%$ in OSe group and $37.30 \%$ in NSe group. The diseases infection showed that diarrhea and respiratory diseases recorded the highest percentages of infections followed by septicemia. The high percentages of diseases incidence presented in this study might be attributed to the repeat infection of calves. Moreover, the high incidence of diseases was reflected in the high mortality rate in the control group. Morality rate was higher in control group being 33.33\% than that of OSe group being $16.67 \%$, without no calves mortality in NSe group. The reduced diseases infection and mortality rate with organic and nano selenium supplementation could be attributed to the improvement in immunity response. Selenium (Se) is an essential trace element ( $\mathrm{Lu}$ and Holmgren, 2009; Rayman, 2000) that evinces antioxidant activity (Abuelo et al., 2016; Dkhil et al., 2016; Lu et al., 2017; Ju et al., 2017), antiinflammatory (Aaseth et al., 2016; El-Ghazaly et al., 2017; Liu et al., 2017; Malhotra et al., 2016; Speckmann and Steinbrenner, 2014), antimutagenic (Peng et al., 2016; Schrauzer, 2008), anticarcinogenic (Ahmad et al., 2015; Hassan and Webster, 2016; Tran et al., 2010) or chemopreventive (Rao et al., 2001), antiviral (Hefnawy and Tórtora-Pérez, 2010) antibacterial (Cihalova et al., 2015; Guisbiers et al., 2016; Chudobova et al., 2014; Wang et al., 2015), antifungal (Guisbiers et al., 2017; Shakibaie et al., 2015) and antiparasitic effects (Beheshti et al., 2013; Dkhil et al., 2016; Mahmoudvand et al., 2014). Furthermore, it is an integral component of selenoproteins participating in a whole series of physiologically important processes (Pascual and Aranda, 2013). The first proven selenoenzyme was glutathione peroxidase (GPx) (Hefnawy and Tórtora-Pérez, 2010), which is an indispensable component of the antioxidant system in the organism (Arthur, 2000). In inflammatory diseases, the selenium concentration declines and the biosynthesis of selenoproteins is disturbed (Schomburg, 2012). The application of selenium decreases is the indices of inflammatory activity (Köhrle and Gärtner, 2009). Selenium is very important for chemotactic and phagocyte activity and respiratory burst activities. Selenium deficiency leads to decrease of GPx enzyme activity and drop in neutrophil activity as well as making the body cells more susceptible to oxidative damage. (Radostits et al., 2007)

Table (5): The percentages of various diseases infection and mortality rate of suckling Friesian calves.

\begin{tabular}{|c|c|c|c|c|}
\hline \multirow{2}{*}{ Item } & \multicolumn{3}{|c|}{ Treatment } & \multirow{2}{*}{ SEM } \\
\hline & Control & $\mathrm{OSe}$ & $\mathrm{NSe}$ & \\
\hline \multicolumn{5}{|l|}{ Incidence $(\%)$} \\
\hline Diarrhea & $24.80^{\mathrm{a}}$ & $14.90^{\mathrm{b}}$ & $13.45^{\mathrm{b}}$ & 1.60 \\
\hline Mortality rate $\%$ & $(2 / 6) 33.33^{\mathrm{a}}$ & $(1 / 6) 16.67^{\mathrm{b}}$ & $(0 / 6) 00.00^{c}$ & 2.35 \\
\hline
\end{tabular}

$a, b, c$ Means in the same row with unlike superscripts letter are significantly different $(P<0.05)$.




\section{Feed intake:}

Data in Table (6) revealed that the intake of whole milk, calf starter and berseem hay as well as dry matter intake (DM) were the same for different groups. Whereas, TDN and DCP intake tended to increase with OSe and NSe supplementation than those of control group. The slight increase in TDN and DCP intake may be attributed to the increase of TDN and DCP values of experimental rations with selenium supplementation. Ibrahim (2017) found significant improvement $(\mathrm{P}<0.05)$ in feed intakes (DCPI and TDNI) for lambs received vit. E and selenium when compared to control.

Table (6): Average daily feed intake by experimental suckling calves (during the experimental period, 105 days).

\begin{tabular}{lcccc}
\hline \multirow{2}{*}{ Item } & \multicolumn{2}{c}{ Treatment } & \multirow{2}{*}{ SEM } \\
\cline { 2 - 3 } & Control & OSe & NSe & \\
As fed (kg/day): & 3.03 & 3.03 & 3.03 & \\
Whole milk & 0.82 & 0.82 & 0.82 & \\
Calf starter & 0.33 & 0.33 & 0.33 & 0.05 \\
Berseem hay & & & 1.40 & 0.04 \\
As DM (kg/day) & 1.40 & 1.40 & 1.10 & 0.01 \\
DM & 1.07 & 1.11 & 0.184 & \\
TDN & 0.175 & 0.188 & & \\
DCP & & & & \\
\hline
\end{tabular}

\section{Live body weight and weight gain:}

Results in Table (7) showed that birth weight was neatly similar for the different groups without significant differences. While, weaning weight, total weight gain and average daily gains were significantly $(\mathrm{P}<0.05)$ higher for OSe and NSe groups than untreated group. Average daily gain of OSe and NSe supplemented groups increased by 125 and 119 g/day or by 27.13 and $25.83 \%$ compared to control group. Selenium affect the formation and activation of thyroid hormones which consequently the growth performance. Wichtel et al. (1996) recoded that Frisian calves fed ration as pellets supplemented with selenium increased the average body weight gain than calves fed ration without selenium additive (control group). Spears et al. (1986) noticed that calves injected with $5.5 \mathrm{mg}$ selenium and $75 \mathrm{IU}$ Vitamin E /100 kg live body weight at sixty days intervals from $1^{\text {st }}$ to $5^{\text {th }}$ or $7^{\text {th }}$ increased weaning weight in calves compared with un-treated calves. Reffett et al. (1986) found that calf weight gains increased in first 14 days after weaning with selenium injection at $15 \mathrm{mg} / \mathrm{head}$. Same result were obtained on goats by Yuhua et al. (1996)

Table (7): Body weight and weight gain of suckling calves.

\begin{tabular}{|c|c|c|c|c|}
\hline \multirow{2}{*}{ Item } & \multicolumn{3}{|c|}{ Treatment } & \multirow{2}{*}{ SEM } \\
\hline & Control & $\mathrm{OSe}$ & $\mathrm{NSe}$ & \\
\hline Birth weight (kg) & 29.50 & 30.06 & 28.94 & 0.67 \\
\hline Weaning weight $(\mathrm{kg})$ & $77.88^{\mathrm{b}}$ & $91.56^{\mathrm{a}}$ & $89.81^{\mathrm{a}}$ & 2.93 \\
\hline Total weight gain $(\mathrm{kg})$ & $48.38^{\mathrm{b}}$ & $61.50^{\mathrm{a}}$ & $60.87^{\mathrm{a}}$ & 2.46 \\
\hline Average daily gain $(\mathrm{g})$ & $460.71^{\mathrm{b}}$ & $585.71^{\mathrm{a}}$ & $579.71^{\mathrm{a}}$ & 23.41 \\
\hline
\end{tabular}

$a, b$ Means in the same row with unlike superscripts letters are significantly different $(P<0.05)$.

Castellan et al. (1999) indicated that inserted selenium in to maternal diet at the level of $0.05 \mathrm{mg} / \mathrm{kg}$ within 2 days of after giving birth and on 70,114 and 149 led to higher mean daily gain compared with control group. Selenium is available in inorganic and organic forms. Common inorganic forms include sodium selenite and selenate. Organic form exists as seleno methionine. Selenium yeast as organic form is higher digestible compared with inorganic form (sodium selenite) (Pagan et al., 1999). Guyot et al. (2007) indicated that calves fed ration including seleno-yeast $(\mathrm{y}-\mathrm{Se})$ at the level of $0.5 \mathrm{ppm}$ reached higher growth performance compared with calves fed diets containing sodium selenite as inorganic selenium. Lambs achieved humoral immune response, enhanced growth performance, and antioxidant situation when they fed diet with $0.15 \mathrm{ppm}$ selenium as sodium selenite or selenium (Jevsel-101) as marketing name compared with 


\section{Shams et al.}

lambs fed diets without selenium additive control (Kumar et al., 2009) and the effect being lower for inorganic selenium animals than those fed organic selenium supplemented ration.

\section{Feed conversion:}

Feed conversion in Table (8) revealed that OSe and NSe supplementation improved feed conversion ratio, which led to significant decrease $(\mathrm{P}<0.05)$ in the amounts of DM, TDN and DCP required for producing one kg weight gain compared to control group. Ibrahim (2017) found that feed conversion (FCR, DCPI and TDNI) improved $(\mathrm{P}<0.05)$ for lambs received vit. E and selenium compared to control. In case of Se supplementation, the beneficial effects on animal performance were detected in studies on sheep (Kumar et al., 2009) and goats (Kamdev et al., 2015).

\section{Economic efficiency:}

Results of economic efficiency (Table 8) showed that the cost of feed intake was the same for different groups, which the cost of OSe and NSe was negligible due to the less amount of Se additive $0.42 \mathrm{mg} / \mathrm{day}$. The feed cost for producing one kg weight gain was significantly $(\mathrm{P}<0.05)$ lower for OSe and NSe groups compared to control group, being 41.46, 32.61 and $32.95 \mathrm{LE} / \mathrm{kg}$ weight gain for control, OSe and NSe groups, respectively. However, the price of daily weight gain and net revenue as well as economic efficiency expressed as the ratio between price of daily weight gain and daily feed cost were significantly $(\mathrm{P}<0.05)$ higher for OSe and NSe groups compared to control group. Economic efficiency improved significantly $(\mathrm{P}<0.05)$ by 27.32 and $25.85 \%$ for OSe and NSe groups compared to control group, respectively. In cattle, selenium deficiency can have economically significant impacts such as reduced fertility, placental retentions, and the incidence of mastitis and merits (Spears and Weiss, 2008; Hefnawy and Tórtora-Pérez, 2010; Sordillo, 2013). According to Eulogio et al. (2012) the performance and economic feasibility of the use of selenium and vitamin E allowed to obtain a profit margin of 0.21 \$US per animal per day.

Table (8): Feed conversion and economic efficiency of suckling calves.

\begin{tabular}{|c|c|c|c|c|}
\hline \multirow{2}{*}{ Item } & \multicolumn{3}{|c|}{ Treatment } & \multirow{2}{*}{ SEM } \\
\hline & Control & $\mathrm{OSe}$ & $\mathrm{NSe}$ & \\
\hline \multicolumn{5}{|l|}{ Feed conversion } \\
\hline DM (kg/kg gain) & $3.04^{\mathrm{a}}$ & $2.42^{\mathrm{b}}$ & $2.42^{\mathrm{b}}$ & 0.11 \\
\hline TDN (kg/ kg gain) & $2.33^{\mathrm{a}}$ & $1.92^{\mathrm{b}}$ & $1.90^{\mathrm{b}}$ & 0.08 \\
\hline $\mathrm{DCP}(\mathrm{g} / \mathrm{kg}$ gain $)$ & $380.29^{\mathrm{a}}$ & $325.20^{\mathrm{b}}$ & $317.40^{\mathrm{b}}$ & 13.03 \\
\hline \multicolumn{5}{|l|}{ Economic efficiency } \\
\hline Daily feed cost LE & 19.10 & 19.10 & 19.10 & 0.07 \\
\hline Feed cost LE/kg gain & $41.46^{\mathrm{a}}$ & $32.61^{\mathrm{b}}$ & $32.95^{\mathrm{b}}$ & 1.50 \\
\hline Price of daily gain LE & $39.16^{\mathrm{b}}$ & $49.79^{\mathrm{a}}$ & $49.28^{\mathrm{a}}$ & 1.99 \\
\hline Net revenue LE & $20.06^{\mathrm{b}}$ & $30.69^{\mathrm{a}}$ & $30.18^{\mathrm{a}}$ & 1.95 \\
\hline Economic efficiency & $2.05^{\mathrm{b}}$ & $2.61^{\mathrm{a}}$ & $2.58^{\mathrm{a}}$ & 0.10 \\
\hline Economic improvement $\%$ & $00.00^{\mathrm{b}}$ & $27.32^{\mathrm{a}}$ & $25.85^{\mathrm{a}}$ & 1.36 \\
\hline
\end{tabular}

$a, b$ Means in the same row with unlike superscripts are significantly different $(P<0.05)$.

Economic improvement $\%=\frac{\text { ose-control }}{\text { control } 100}$

\section{CONCLUSION}

From the present study it could be concluded that organic selenium (OSe) and nano selenium (NSe) supplementation for suckling Friesian calves has led to significant improvement of feed digestibility, blood biochemical measurement, immunity response, health status, growth rate, feed conversion and economic efficiency as well as reduce mortality rate. 


\section{ACKNOWLEDGMENT}

This work was financially supported within the framework of the project "Biological production of nanoselenium spheres and its application in livestock production" by the National Strategy for Genetic Engineering and Biotechnology, Academy of Scientific Research and Technology, Egypt.

\section{REFERENCES}

Aaseth, J.; Alexander, J.; Bjørklund, G.; Hestad, K.; Dusek, P.; Roos, P.M. and Alehagen, U. (2016) . Treatment strategies in Alzheimer's disease: A review with focus on selenium supplementation. Biometals, 29: 827-839.

Abd El-Hafez, G.A.; G.M.A. Solouma; A.Y. Kassab and A.S. Ali (2016). Some reproductive performance of male lambs and feeding values of rations as affected by supplementation of different selenium sources. Egyptian J. Nutrition and Feeds, 19 (1): 103-114.

Abuelo, A.; Alves-Nores, V.; Hernandez, J.; Muiño, R.; Benedito, J.L. and Castillo, C. (2016). Effect of parenteral antioxidant supplementation during the dry period on postpartum glucose tolerance in dairy cows. J. Vet. Int. Med., 30: 892-898.

Ahmad, M.S.; Yasser, M.M.; Sholkamy, E.N.; Ali, A.M. and Mehanni, M.M.( 2015). Anticancer activity of biostabilized selenium nanorods synthesized by Streptomyces bikiniensis strain Ess_amA-1. Int. J. Nanomed. 10: 3389-3401.

Animal Production Research Institute (1997). Animal Nutrition Scientifically and Practically. $1^{\text {st }}$ Ed. Animal Production Research Institute, Agriculture Research Center, Ministry of Agriculture, Dokki, Giza, Egypt (In Arabic).

AOAC (1990). Association of Official Analytical Chemists, Official Methods of Analysis, Washington, vol. $1 ., 15^{\text {th }}$ ed. $p p$ 69-90.

Arthur, J.R. (2000). The glutathione peroxidases. Cell Mol. Life Sci., 57: 1825-1835.

Beheshti, N.; Soflaei, S.; Shakibaie, M.; Yazdi, M.H.; Ghaffarifar, F.; Dalimi, A.; Shahverdi, A.R. (2013) . Efficacy of biogenic selenium nanoparticles against Leishmania major: In vitro and in vivo studies. $J$. Trace Elem. Med. Biol., 27: 203-207.

Bunglavan, S. J.; A. K. Garg; R. S. Dass and S. Shrivastava (2014). Effect of supplementation of different levels of selenium as nanoparticles/sodium selenite on blood biochemical profile and humoral immunity in male Wistar rats. Veterinary World, 7(12): 1075-1081.

Castellan, D.M.; J.P. Maas; I.A. Gardner; J.W. Oltjen and Sween M. L. (1999): Growth of suckling beef calves in response to parenteral administration of selenium and the effect of dietary protein provided to their dams. J. Am. Vet. Med. Ass. 15: 816-821.

Chasson, A. L., Grady, H. J. and Stanley, M. A. (1961). Determination of creatinine by means of automatic chemical analysis. Amer. J. clin. Path., 35: 83.

Chudobova, D.; K. Cihalova; S. Dostalova; B. Ruttkay-Nedecky; M.A.M. Rodrigo; K. Tmejova; P. Kopel; L. Nejdl; J. Kudr; J. Gumulec; S. Krizkova; J. Kynicky; R. Kizek and V. Adam (2014), Comparison of the effects of silver phosphate and selenium nanoparticles on Staphylococcus aureus growth reveals potential for selenium particles to prevent infection. FEMS Microbiol Lett, 351: 195-201.

Cihalova, K.; Chudobova, D.; Michalek, P.; Moulick, A.; Guran, R.; Kopel, P.; Adam, V. and Kizek, R. (2015).Staphylococcus aureus and MRSA Growth and Biofilm Formation after Treatment with Antibiotics and SeNPs. Int. J. Mol. Sci., 16, 24656-24672.

Dercksen, D.P.; Counotte, G.H.; Hazebroek, M.K.; Arts, W. and van Rijn, T. (2007). Selenium requirements of dairy goats [Article in Dutch]. Tijdschr Diergeneeskd, 132: 468-471. 


\section{Shams et al.}

Dkhil, M.A.; Zrieq, R.; Al-Quraishy, S. and Abdel Moneim, A.E.( 2016). Selenium nanoparticles attenuate oxidative stress and testicular damage in streptozotocin-induced diabetic rats. Molecules, 21: 1517.

Effraimidis, G.; . and Wiersinga, W.M. (2014) . Mechanisms in endocrinology: Autoimmunethyroid disease: Old and new players. Eur. J. Endocrinol. 170: R241-R252.

El-Ghazaly, M.A.; Fadel, N.; Rashed, E.; El-Batal, A. and Kenawy, S.A. (2017). Anti-inflammatory effect of selenium nanoparticles on the inflammation induced in irradiated rats. Can. J. Physiol. Pharmacol. 95: $101-110$.

Eulogio, G.L.J.; Hugo, C.V.; Antonio, C.N.; Alejandro, C.-I. and Juan, M.Q.( 2012). Effects of the selenium and vitamin $\mathrm{E}$ in the production, physicochemical composition and somatic cell count in milk of Ayrshire cows. J. Anim.Vet. Adv. 11: 687-691.

FNB ( Food and Nutrition Board ) : Institute of Medicine ( 2000 ) Dietary Reference Intake for Vitamin C , Vitamin E, Selenium and Carotenoids . National Academy Press : Washington, DC .

Gill, H. and Walker, G.( 2008). Selenium, immune function and resistance to viral infections. Nutr.Dietetics 65: $41-47$

Guisbiers, G.; Lara, H.H.; Mendoza-Cruz, R.; Naranjo, G.; Vincent, B.A.; Peralta, X.G. and Nash, K.L.( 2017 ). Inhibition of Candida albicans biofilm by pure selenium nanoparticles synthesized by pulsed laser ablation in liquids. Nanomedicine 13: 1095-1103.

Guisbiers, G.; Wang, Q.; Khachatryan, E.; Mimun, L.C.; Mendoza-Cruz, R.; Larese-Casanova, P.; Webster, T.J. and Nash, K.L. (2016 ). Inhibition of E. coli and S. aureus with selenium nanoparticles synthesized by pulsed laser ablation in deionized water. Int. J. Nanomed. 11:3731-3736.

Guyot, H.; P. Spring; S. Andrieu and F. Rollin (2007). Comparative responses to sodium selenite and organic selenium supplements in Belgium Blue cows and calves. Livest. Sci., 111: 259-263.

Hafkenscheid, J. C. and C. C. Dijt (1979). Determination of serum aminotransferases: activation by pyridoxal-5'-phosphate in relation to substrate concentration. Clinical Chemistry, 25(1): 55-59,

Hassan, C.E.and Webster, T.J. (2016 ).The effect of red-allotrope selenium nanoparticles on head and neck squamous cell viability and growth. Int. J. Nanomed. 11:3641-3654.

Hefnawy, A.E.G.and Tórtora-Pérez, J.L.( 2010 ). The importance of selenium and the effects of its deficiency in animal health. Small Rumin. Res. 89: 185-192.

Henry, R.J., Canmon, D.C. and Winkelman, J.W. (1974). Principles and techniques, Harper and Row. Clin. Chem., pp. 415.

IBM SPSS Statistics (2014). Statistical package for the social sciences, Release 22, SPSS INC, Chicago, USA.

Ibrahim, E. M. (2017). Effect of parenteral supplementation of vitamin E plus selenium on nutrient digestibility, productive performance and some serum biochemical indicators of lambs, Egyptian Journal of Sheep \& Goat Sciences, 12 (1): 59-70 .

Ježek, P., Škarpa, P., Lošák, T., Hlušek, J., Jůzl, M. and Elzner, P. (2012). Selenium-an important antioxidant in crops biofortification. In: El-Missiry, M. A. (ed) Antioxidant enzyme. ISBN 978-953-510789-7. doi: 10.5772/50356.

Ju, W.; Li, X.; Li, Z.; Wu, G.R.; Fu, X.F.; Yang, X.M.; Zhang, X.Q. and Gao, X.B.( 2017 ). The effect of selenium supplementation on coronary heart disease: A systematic review and meta-analysis of randomized controlled trials. J. Trace Elem. Med. Biol. 44: 8-16.

Kamdev, S.; C. Mishra; S.K. Mishra; R.K. Swain; K. Behera and G.P. Mohanty (2015): Effect of sodium selenite supplementation in goats. Indian J. of Small Rumin. 21: 129-131.

Kar, T. and Misra, A. K. (1999). Therapeutic properties of whey used as fermented drink. Revista de Microbiologia, 30:163-169.

Keen, CL.; JY. Uriu-Adams; JL. Ensuma and ME. Gershwin (2004). Trace elements minerals and immunity. Handbook of Nutrition and Immunity. Totowa, NJ, USA: Humana Press, pp.117-140 
Köhrle, J. and Gärtner, R. (2009 ). Selenium and thyroid. Best Pract. Res. Clin. Endocrinol. Metab. 23: 815827.

Kumar N., Garg A., Dass R., Chaturvedi V., Mudgal V. and Varshney V. (2009). Selenium supplementation influences growth performance, antioxidant status and immune response in lambs. Anim. Feed Sci. Technol. 153: 77-87.

Liu, J.; Yang, Y.; Zeng, X.; Bo, L.; Jiang, S.; Du, X.; Xie, Y.; Jiang, R.; Zhao, J. and Song, W.( 2017 ). Investigation of selenium pretreatment in the attenuation of lung injury in rats induced by fine particulate matters. Environ. Sci. Pollut.Res. Int. 24: 4008-4017.

Lu, J. and; Holmgren, A.( 2009 ). Selenoproteins. J. Biol. Chem. 284: 723-727.

Lu, X.; Zhang, E.; Yin, S.; Fan, L. and Hu, H. (2017). Methylseleninic Acid prevents patulin-induced hepatotoxicity and nephrotoxicity via the inhibition of oxidative stress and inactivation of p53 and MAPKs. J. Agric. Food Chem. 65: 5299-5305.

Mahmoudvand, H.; Harandi, M.F.; Shakibaie, M.; Aflatoonian, M.R.; ZiaAli, N.; Sadat Makki, M.S. and Jahanbakhsh, S.( 2014 ). Scolicidal effects of biogenic selenium nanoparticles against protoscolices of hydatid cysts. Int. J. Surg. 12:399-403.

Malhotra, S.; Welling, M.N.; Mantri, S.B. and Desai, K.( 2016). In vitro and in vivo antioxidant, cytotoxic, and anti-chronic inflammatory arthritic effect of selenium nanoparticles. J. Biomed. Mater. Res. B Appl. Biomater. 104: 993-1003.

Mudgal, V.; A. K. Garg; R. S. Dass and V. P. Varshney (2008). Effect of selenium and copper supplementation on blood metabolic profile in male buffalo (Bubalus bubalis) calves. Biol.Trace Elem. Res., 121(1): 31-38.

Nampoothiri, V. and P. Ganga Devi (2017): Selenium for calf growth and health: Mini review. International Journal of Livestock Research, 7: 1-10.

Pagan, J.D., P. Karnezos, M.A.P. Kennedy, T. Currier and K.E. Hoekstra. 1999. Effect of selenium source on selenium digestibility and retention in exercised Thoroughbreds. Proc. Equine Nutrition \& Physiology Soc., Raleigh, N.C.

Parente, E. and Zottola, E. A. (1991). Growth of thermophilic starters in whey permeate media. J. Dairy Sci. $74: 20-28$.

Pascual, A. and Aranda, A. (2013 ). Thyroid hormone receptors, cell growth and differentiation. Biochim. Biophys. Acta 1830: 3908-3916.

Peng, F.; Guo, X.; Li, Z.; Li, C.; Wang, C.; Lv, W.; Wang, J.; Xiao, F.; Kamal, M.A. and Yuan, C. (2016). Antimutagenic effects of selenium-enriched polysaccharides from pyracantha fortuneana through suppression of cytochrome P450 1A subfamily in the mouse liver. Molecules 21: 1731.

Prokisch, J. and M. Zommara (2011). Process for producing elemental selenium Nano-spheres. United States Patent 8,003,071.

Prokisch, J.; É. Széles; B. Kovács; L. Daróczy and M. Zommara (2008). Formation of metal selenium Nanospheres in bacteria: is it a possible detoxification mechanism? VII. Alps-Adria Scientific Workshop Stara Lesna, Slovakia, Suppl.1, pp. 947-952.

Quintana, M., Haro-Poniatowski, E., Morales, J. and Batina, N. (2002). Synthesis of selenium nanoparticles by pulsed laser ablation. Appl. Surf. Sci., 195: 175-186.

Radostits, O.M.; Gay, C.C.; Hinchcliff, K.W. and Constable, P.D. (2007). Veterinary Medicine: A Textbook of the Diseases of Cattle, Horses, Sheep, Pigs and Goats, 10th ed.; Saunders: Madrid, Spain, pp. 552557.

Ramamurthy, C. H., Sampath, K. S., Arunkumar, P., Kumar, M. S., Sujatha, V., Premkumar, K. and Thirunavukkarasu, C. (2013). Green synthesis and characterization of selenium nanoparticles and its augmented cytotoxicity with doxorubicin on cancer cells. Bioprocess Biosyst. Eng., 36: 1131-1139. 


\section{Shams et al.}

Rao, L.; Puschner, B. and Prolla, T.A. (2001 ). Gene expression profiling of low selenium status in the mouse intestine: Transcriptional activation of genes linked to DNA damage, cell cycle control and oxidative stress. J. Nutr. 131: 3175-3181.

Rayman, M.P. (2000). The importance of selenium to human health. Lancet, 356: 233-241.

Reffett, J.K., Spears, J.W. and Brown, T.T. Jr. (1988).Effect of dietary selenium on the primary and secondary immune response in calves challenged with infectious bovine rhinotracheitis virus. J.Nutr., 118: $229-235$

Reffett. J.K., Spears, J.W., Hatch, P.A. and Brown, T.T. (1986). Influence of selenium and zinc on performance, blood constituents and immune response in stressed calves. Biol. Trace Ele. Res., 9:139149.

Salles, M.S.V.; M.A. Zanetti; L.C.R. Júnior and Yara M. Lucisano-Valim (2013). Performance and immune response of suckling calves fed organic selenium. Animal Feed Science and Technology, 188: 28-35.

Schomburg, L. (2012 ). Selenium, selenoproteins and the thyroid gland: Interactions in health and disease. Nat. Rev. Endocrinol. 8: 160-171.

Schrauzer, G.N.( 2008 ). Effects of selenium and low levels of lead on mammary tumor development and growth in MMTV-infected female mice. Biol. Trace Elem. Res., 125: 268-275.

Serra AB. Nakamura K. Matsui T. Harumoto T. and Fujihara RI (1994) Inorganic selenium for sheep: II. Its influence on rumen bacterial yield, volatile fatty acid production and total tract digestion of timothy hay. J Anim. Sci., 7:91-96

Shakibaie, M.; Salari Mohazab, N. and Ayatollahi Mousavi, S.A. (2015 ). Antifungal Activity of Selenium Nanoparticles Synthesized by Bacillus species Msh-1 Against Aspergillus fumigatus and Candida albicans. Jundishapur J. Microbiol., 8: e26381.

Shoeibi, S. and Mashreghi, M. (2017). Biosynthesis of selenium nanoparticles using Enterococcus faecalis and evaluation of their antibacterial activities. J. Trace. Elem. Med. Biol., 39:135-139.

Sordillo, L.M.( 2013 ). Selenium-dependent regulation of oxidative stress and immunity in periparturient dairy cattle. Vet. Med. Int., 2013: 154045.

Spears, J.W.; Harvey, R.W. and Segerson, E.C. (1986) Effects of marginal deficiency and winter protein supplementation on growth, reproduction, and selenium status of beef cattle. J. Anim. Sci. 63: 586-594.

Spears, J.W.; . and Weiss, W.P. (2008 ). Role of antioxidants and trace elements in health and immunity of transition dairy cows. Vet. J., 176: 70-76

Speckmann, B. and Steinbrenner, H. (2014 ). Selenium and selenoproteins in inflammatory bowel diseases and experimental colitis. Inflamm. Bowel Dis. 20: 1110-1119.

Sunde, R. A. (2012). Selenium. In: Ross, A. C., Caballero, B., Cousins, R. J., Tucker, K. L. and Ziegler, T.R., eds. Modern nutrition in health and disease. 11th ed. Philadelphia, PA: Lippincott Williams \& Wilkins:225-237.

Terry, E. N. and Diamond, A. M. (2012). Selenium. In: Erdman, J. W., Macdonald, I. A., Zeisel, S. H., eds. Present knowledge in nutrition. 10th ed. Washington, DC: Wiley-Blackwell, 568-587.

Tran, P.A.; Sarin, L.; Hurt, R.H. and Webster, T.J. (2010). Differential effects of Nano selenium doping on healthy and cancerous osteoblasts in coculture on titanium. Int. J. Nanomed. 5: 351-358.

Van Keulen, J. and Young B. A. (1977): Evaluation of acid insoluble ash as a natural marker in ruminant digestibility studies. J. Anim. Sci., 44:282

Vinu, M. N.; Gangadevi P.; Mercy A. D.; Anil K. S. and Shyama K. (2012). Effect of dietary supplementation of organic selenium on growth performance and nutrient utilization in crossbred calves. J. Vet. Anim. Sci., 43:36-40.

Wang, Q.; Larese-Casanova, P. and Webster, T.J.( 2015 ). Inhibition of various gram-positive and gramnegative bacteria growth on selenium nanoparticle coated paper towels. Int. J. Nanomed. 10: 2885-2894. 
Wichtel, J.J.; Craigie, A.L.; Freeman, D.A.; Varela-Alvarez, H. and Williamson, N.B. (1996 ). Effect of selenium and iodine supplementation on growth rate and on thyroid and somatotropic function in dairy calves at pasture. J. Dairy Sci. 79:1865-1872.

Willshire, J.A. and Payne J.H. (2011): Selenium and vitamin E in dairy cows - a review. Cattle Pract. 19: 22-30.

Xun W.; L. Shi; Yue W.; Zhang C.; Ren Y. and Qiang (2012). Effect of High-Dose Nano-selenium and Selenium-Yeast on Feed Digestibility, Rumen Fe mentation, and Purine Derivatives in Sheep. Liu Biol. Trace Elem. Res., 150:130-136.

Yuhua, L.; Xingsuo W.; and Xiutian D. (1996): Effects of selenium supplementation in Diet on the ruminal digestion and metabolism of goats. Acta Agric. Univ. Henanensis. 1: 1-7.

Zhang, S. Y., Zhang, J., Wang, H. Y. and Chen, H. Y. (2004). Synthesis of selenium nanoparticles in the presence of polysaccharides. Mater Lett., 58: 2590-2594.

Zommara, M. and Prokisch J. (2015). Selenium rich yoghurt: Bio-fortification for better health. Egyptian J. Dairy Sci., 43: 159-167.

\title{
أداء النمو والإستجابة المناعية للعجول الفريزيان الرضيعة مع إضافة السيلينيوم العضوى و النانو المنتج بواسطة بكتيريا حامض اللاكتيك
}

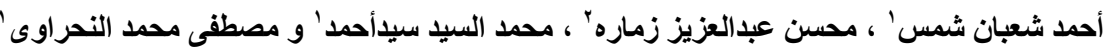 \\ ' معهج بحوث الاتتاج الحيوانس- مركز البحوث الزراعيةـ الدقى- الجبزة- مصر.

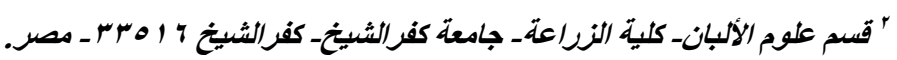

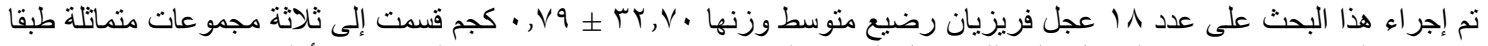

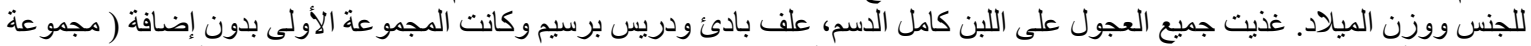

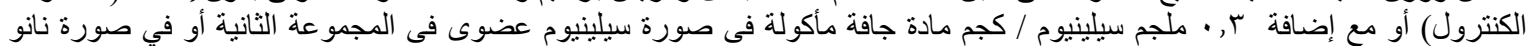

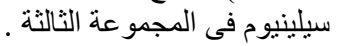

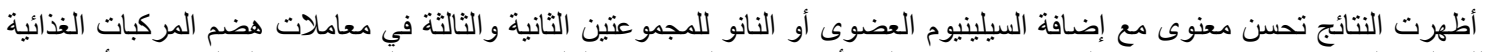

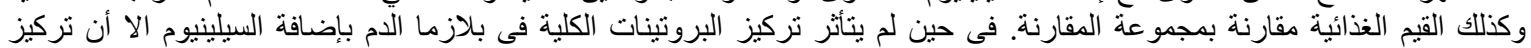

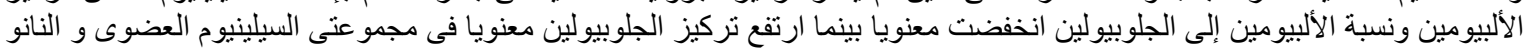

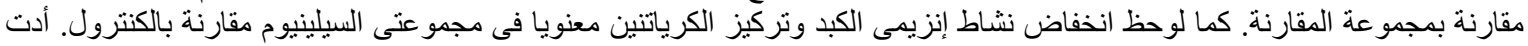

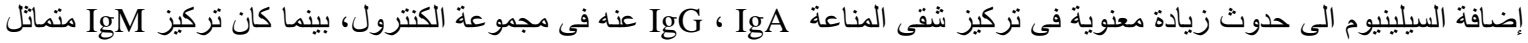
تقريبا فى المجموعات الثلاثة.

انخفضت معنوياً نسبة الإصابة بالأمر اض المختلفة فى مجمو عتى السيلينيوم مقارنة بالكنترول، وارتفع معدل النفوق فى مجمو عة المقارنة

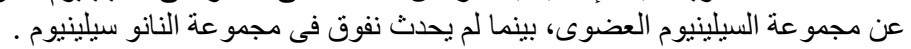

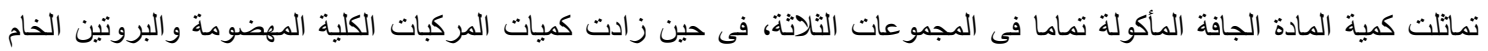

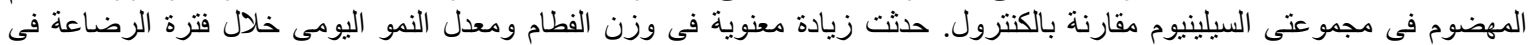
مجمو عنى السيلينيوم العضوى و النانو مقارنة بمجمو عة المقارنة.

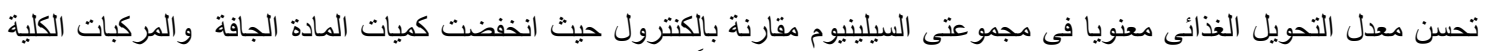

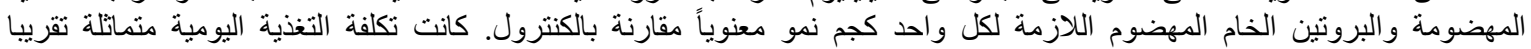

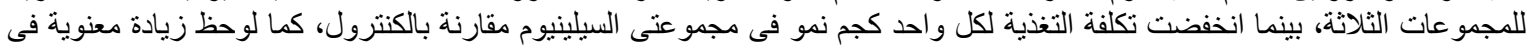

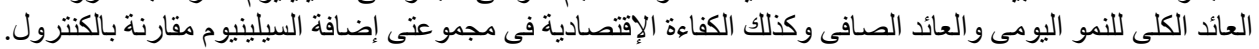

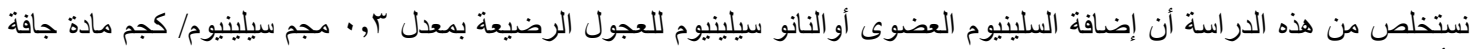

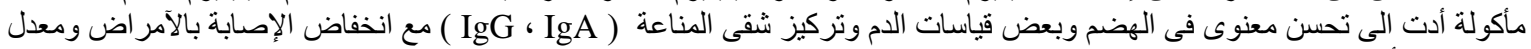
النفوق. كما أدت إلى تحسن معنوى فى معى الحدل النمو و معدل التحويل الغذائى و الكفاءة الاقتصنادية.
\end{abstract}


Shams et al. 